\section{High Tunnel Apricot Production in Frost-prone Northern New Mexico}

\author{
Shengrui $\mathrm{YaO}^{1,2,3}$, Steve Guldan ${ }^{1,2}$, and Robert Heyduck ${ }^{2}$
}

Additional index words. bud drop, flower bud damage, Prunus armeniaca, weather conditions, yield

SumMARY. Late frost is the number one issue challenging fruit production in northern New Mexico. We had apricot (Prunus armeniaca) trees in an open field planting at Alcalde, NM, and not a single fruit was harvested from 2001 through 2014. Apricot trees in surrounding communities produce sporadic crops. In 2012 , we planted apricots in two $16 \times 40-\mathrm{ft}$ high tunnels $(9.5-\mathrm{ft}$ high point). Trees were trained to a spindle system in one high tunnel and an upright fruiting offshoot (UFO) system in the other, and there were identical plantings in the open field for each high tunnel. Supplemental heating was provided starting at blooming time. There were five cultivars planted in each high tunnel at $4 \times 8$ - $\mathrm{ft}$ spacing in a randomized complete block design with two replications (rows) and two trees per cultivar in each plot. In 2015, relatively high yields were obtained from all cultivars. The average yields for the spindle system were (lb/tree): 'Puget Gold' (29.0), 'Harcot' (24.1), 'Golden Amber' (19.6), 'Chinese Apricot' (18.6), and 'Katy' (16.7). Yields for the UFO system were (lb/tree): 'Golden Amber' (18.6), 'Katy' (14.9), 'Puget Gold' (11.3), 'Chinese Apricot' (10.2), and 'Harcot' (8.6). On average across all cultivars, the UFO system produced $60 \%$ of the yield of the spindle system in 2015. A heating device is necessary for high tunnel apricot fruit production in northern New Mexico because trees normally bloom in early to late March, depending on the year, while frosts can continue until mid-May. In years like 2017 and 2018 with temperatures below $10^{\circ} \mathrm{F}$ in late February/early March, some of the expanded flower buds were killed before bloom. On those cold nights, one 100-1b tank of propane may or may not be enough for 1 night's frost protection. Economically, it would not be feasible in those years. Only in years with a cool spring, late-blooming trees, and mild temperatures in April and May can high tunnel apricot production generate positive revenue with high, direct-market prices. High tunnel apricot production with heating devices is still risky and cannot guarantee a reliable crop in northern New Mexico or similar areas.

A pricots are the first fruit species to bloom each spring in northern New Mexico, with blooming dates ranging from early to late March-or as late as 10 Apr. in 2010 - depending on the cultivar and weather conditions each year.

Received for publication 12 Feb. 2019. Accepted for publication 19 Apr. 2019.

Published online 30 May 2019.

We thank Richard Heerema and Frank Sholedice from New Mexico State University for their critical review of this manuscript before submission. We acknowledge technical assistance from David Salazar, David Archuleta, Estevan Herrera, and Margarito Hernandez. This project was partially supported by Hatch funds from the U.S. Department of Agriculture, National Institute of Food and Agriculture, and the New Mexico State University Agricultural Experiment Station.

${ }^{1}$ Department of Plant and Environmental Sciences, New Mexico State University, Alcalde, NM 87511

${ }^{2}$ Sustainable Agriculture Science Center at Alcalde, New Mexico State University, Alcalde, NM 87511

${ }^{3}$ Corresponding author. E-mail: yaos@nmsu.edu.

This is an open access article distributed under the CC BY-NC-ND license (https://creativecommons.org/ licenses/by-nc-nd/4.0/).

https://doi.org/10.21273/HORTTECH04315-19
Apricot is well known for its erratic fruit set and yield fluctuation from year to year, even in some major apricot-producing areas (Bassi et al., 1995; Gunes, 2006; Julian et al., 2007). Among 24 apricot trees representing six cultivars at Alcalde, NM, flower buds/fruitlets were killed with repeated late frosts, and not a single fruit was harvested from 2001 through 2014.

Late frost is the critical issue challenging fruit production in central and northern New Mexico, especially for apricot production. Fruit growers have to wait until mid-May each year to confirm whether they have a crop. To help those frustrated fruit growers, we tested alternative tree fruit like jujube (Ziziphus jujuba), berry species such as strawberry (Fragaria Xananassa), and blackberry (Rubus sp.) and alternative production methods such as high tunnel fruit production (Huang et al., 2017; Yao et al., 2015a, 2015b, 2018).

High tunnels have been widely used in vegetable, flower, and fruit production worldwide (Demchak, 2009). They can advance the fruit harvest season 2 to 3 weeks in summer or extend the season 2 to 3 weeks in the fall without heating equipment (Yao and Rosen, 2011; Yao et al., 2018). High tunnels create a protected microclimate that can help manage late frosts in late frost-prone areas. The objective of this study was to test the feasibility of apricot production in high tunnels in northern New Mexico.

\section{Materials and methods}

This experiment was conducted at the New Mexico State University Sustainable Agriculture Science Center at Alcalde, NM [NMSU Alcalde Center; lat. $36^{\circ} 05^{\prime} 27.94^{\prime \prime} \mathrm{N}$, long. $106^{\circ} 03^{\prime} 24.56^{\prime \prime} \mathrm{W}$, elevation $5680 \mathrm{ft}$, average annual precipitation 10.0 inches (Western Regional Climate Center, 2019)]. Based on 2011-17 data from the NMSU Alcalde Center's weather station, the average last spring freeze $\left(32^{\circ} \mathrm{F}\right)$ date was 9 May and the average first fall freeze date was 9 Oct., for a 153-d frost-free growing season (New Mexico Climate Center, 2012). In Apr. 2012, five apricot cultivars were planted at $4 \times 8$ - $\mathrm{ft}$ spacing (in row $\times$ between row spacing) in two $16 \times 40-\mathrm{ft}$ high

\begin{tabular}{llll}
\hline $\begin{array}{l}\text { Units } \\
\text { To convert U.S. to SI, } \\
\text { multiply by }\end{array}$ & U.S. unit & SI unit & $\begin{array}{l}\text { To convert SI to U.S., } \\
\text { multiply by }\end{array}$ \\
\hline $1.055 \mathrm{l}$ & $\mathrm{Btu}$ & $\mathrm{kJ}$ & 0.9478 \\
0.3048 & $\mathrm{ft}$ & $\mathrm{m}$ & 3.2808 \\
3.7854 & $\mathrm{gal}$ & $\mathrm{L}$ & 0.2642 \\
2.54 & inch $(\mathrm{es})$ & $\mathrm{cm}$ & 0.3937 \\
0.4536 & $\mathrm{lb}$ & $\mathrm{kg}$ & 2.2046 \\
1.1209 & $\mathrm{lb} / \mathrm{acre}$ & $\mathrm{kg} \cdot \mathrm{ha}^{-1}$ & 0.8922 \\
0.0254 & $\mathrm{mil}(\mathrm{s})$ & $\mathrm{mm}$ & 39.3701 \\
28.3495 & $\mathrm{Oz}$ & $\mathrm{g}$ & 0.0353 \\
0.9464 & $\mathrm{qt}$ & $\mathrm{L}$ & 1.0567 \\
$\left({ }^{\circ} \mathrm{F}-32\right) \div 1.8$ & ${ }^{\circ} \mathrm{F}$ & ${ }^{\circ} \mathrm{C}$ & $\left({ }^{\circ} \mathrm{C} \times 1.8\right)+32$ \\
& & &
\end{tabular}


tunnels and were trained to a free standing (spindle) system in one high tunnel and upright fruiting offshoots (UFO) system in the other tunnel. The experiment was a randomized complete block design with two replicates (rows) in each tunnel and two trees per cultivar in each row. Each high tunnel had an identical planting in the open field near the high tunnels. The five apricot cultivars were Chinese Apricot, Golden Amber, Harcot, Katy, and Puget Gold. All trees were on 'Marianna 2624' plum (Prunus cerasifera $\times$ Prunus munsoniana) rootstock.

The main structure of the high tunnel consisted of vertical metal posts $4 \mathrm{ft}$ apart extending to $4 \mathrm{ft}$ aboveground, with 2 -inch polyvinyl chloride pipe arched to form a roof peak of $9.5 \mathrm{ft}$. The high tunnel had double doors at each end $(7 \mathrm{ft}$ high $\times$ $6 \mathrm{ft}$ wide) and roll-up sides. The high tunnel was glazed with 8 -mil woven polyethylene sheeting (Solarig 172; J\&M Industries, Ponchatoula, LA), which was installed after planting the trees. High tunnel sides were fully open from planting throughout the 2014 growing season.

The soil was Fruitland sandy loam [coarse-loamy, mixed, calcareous, mesic Typic Torriorthents (U.S. Department of Agriculture, 2008)] with $1.6 \%$ to $1.7 \%$ organic matter in the top 6 inches of soil, and the $\mathrm{pH}$ was 7.9 to 8.0 ( $1: 1$ water extraction; Yao et al., 2018). Cotton seed meal $(7.0 \mathrm{~N}-0.9 \mathrm{P}-0.8 \mathrm{~K})$ was applied at a rate of $50 \mathrm{lb} /$ acre before planting. An organic $2.0 \mathrm{~N}-1.7 \mathrm{P}-0.8 \mathrm{~K}$ fish fertilizer (Neptune's Harvest, Gloucester, MA) was applied three to four times at 3-week intervals May through July at a rate of 2 qt per high tunnel in 2015; two applications were made in May and June in 2017 and 2018. Two 0.5 -inch-diameter polyethylene irrigation tubing lines with 1 -gal/h emitters $\mathrm{l} \mathrm{ft}$ apart were installed along each row after planting. Trees were irrigated once per week for $4 \mathrm{~h}$ in the high tunnel and roughly the same for the open field planting if no precipitation occurred.

From 20 Mar. to 20 May 2015, both sides and doors of high tunnels were closed at night and one 125,000 to $170,000-\mathrm{Btu}$ propane burner with one 100-lb propane tank for each high tunnel was set up with thermostat control set to $32{ }^{\circ} \mathrm{F}$ for frost protection. High tunnels were also closed and supplemental heating started on 20 Mar. for 2016-18.

Each year around blooming time, flower buds were visually checked for possible damage. Pictures were taken as necessary. In 2015 , fruit were harvested from late June to late July as fruit matured for each cultivar. Total yield and fruit number were counted for each tree. Analysis of variance was conducted with Statistix 9 (Analytical Software, Tallahassee, FL) for yield and average fruit weight in each tunnel separately. Fisher's protected least significant difference test was used for mean separation.

\section{Results and discussion}

YIELD. In the 4 years of the study (2015-18), 2015 was the only year with a crop in the high tunnels. There was no fruit in the open field plantings in either the spindle or the UFO system from 2015 to 2018 .

In 2015, 'Katy' and 'Harcot' matured earliest, followed by 'Chinese Apricot', then 'Puget Gold'. 'Golden Amber' was the latest to mature. Among the five cultivars tested, maturation dates ranged from 22 June to 23 July 2015.

For the spindle system, 'Puget Gold' had higher yield than 'Golden Amber', 'Chinese Apricot', and 'Katy', whereas for the UFO system 'Golden Amber' had higher yield than 'Harcot' and 'Chinese Apricot', but not significantly higher than 'Katy' or 'Puget Gold' (Table 1).

'Katy' had larger fruit than others in both spindle and UFO systems (Table 1 ). The smaller fruit of 'Puget Gold' in the spindle system and 'Golden Amber' in the UFO system could be due to their heavy crop load.

Trees in the UFO system on average produced $60 \%$ the crop of those in the spindle system. Since 2015 was the only year with a crop, it is hard to predict their performance in future years. However, the pruning and maintenance of the UFO system was much easier than the spindle system at $4 \times 8$ - $\mathrm{ft}$ planting density. In 2017 and 2018, trees in the spindle system reached the high tunnel ceiling and made the high tunnel shady while the trees in the UFO system were still manageable. Some shoots in the spindle system poked through the roof material, and some shoot tips were killed.

With Santa Fe, NM, and Los Alamos, NM, nearby, growers can get more than $\$ 5.00 / \mathrm{lb}$ for locally grown apricots at local farmers markets like Santa Fe Farmers' Market. Each high tunnel used less than 100 lb of propane in $2015(\$ 81 / 100 \mathrm{lb}$ in 2015 , but price fluctuating with gas price). High tunnel apricots have the potential to be profitable in years like 2015 , with $432 \mathrm{lb}$ total yield in the high tunnel with spindle training and $254 \mathrm{lb}$ for the high tunnel with UFO system.

WeATHer CONDitions 201518. On 24 Jan. 2015, the minimum temperature reached $3{ }^{\circ} \mathrm{F}$ (Fig. 1). Temperatures were warmer through February, March, and April, with a drop to $22^{\circ} \mathrm{F}$ degrees on 18 Apr. 2015. Because trees were still in winter dormancy on 24 Jan., apricot

Table 1. Apricot yield and mean fruit weight of different cultivars in two training systems [spindle and upright fruiting offshoot (UFO)] in high tunnels in 2015 at Alcalde, NM. The yields in each high tunnel/training system were analyzed separately.

\begin{tabular}{llcc}
\hline Cultivar & Training & Yield $(\mathbf{l b} / \text { tree })^{\mathbf{z}}$ & Fruit wt $(\mathbf{g})^{\mathbf{z}}$ \\
\hline Chinese Apricot & Spindle & $18.6 \mathrm{~b}^{\mathrm{y}}$ & $45.7 \mathrm{~b}$ \\
Golden Amber & Spindle & $19.6 \mathrm{~b}$ & $41.0 \mathrm{bc}$ \\
Harcot & Spindle & $24.1 \mathrm{ab}$ & $45.3 \mathrm{~b}$ \\
Katy & Spindle & $16.7 \mathrm{~b}$ & $53.5 \mathrm{a}$ \\
Puget Gold & Spindle & $29.1 \mathrm{a}$ & $39.2 \mathrm{c}$ \\
Chinese Apricot & UFO & $10.2 \mathrm{~b}$ & $46.6 \mathrm{bc}$ \\
Golden Amber & UFO & $18.6 \mathrm{a}$ & $39.7 \mathrm{c}$ \\
Harcot & UFO & $8.6 \mathrm{~b}$ & $53.7 \mathrm{~b}$ \\
Katy & UFO & $14.9 \mathrm{ab}$ & $61.3 \mathrm{a}$ \\
Puget Gold & UFO & $11.3 \mathrm{ab}$ & $53.4 \mathrm{~b}$ \\
\hline
\end{tabular}

${ }^{\mathrm{z}} 1 \mathrm{lb}=0.4536 \mathrm{~kg}, 1 \mathrm{~g}=0.0353 \mathrm{oz}$

${ }^{\mathrm{y}}$ Means within a column and training system not followed by common letters are significantly different at $P \leq 0.05$, by Fisher's protected least significant difference procedure. 


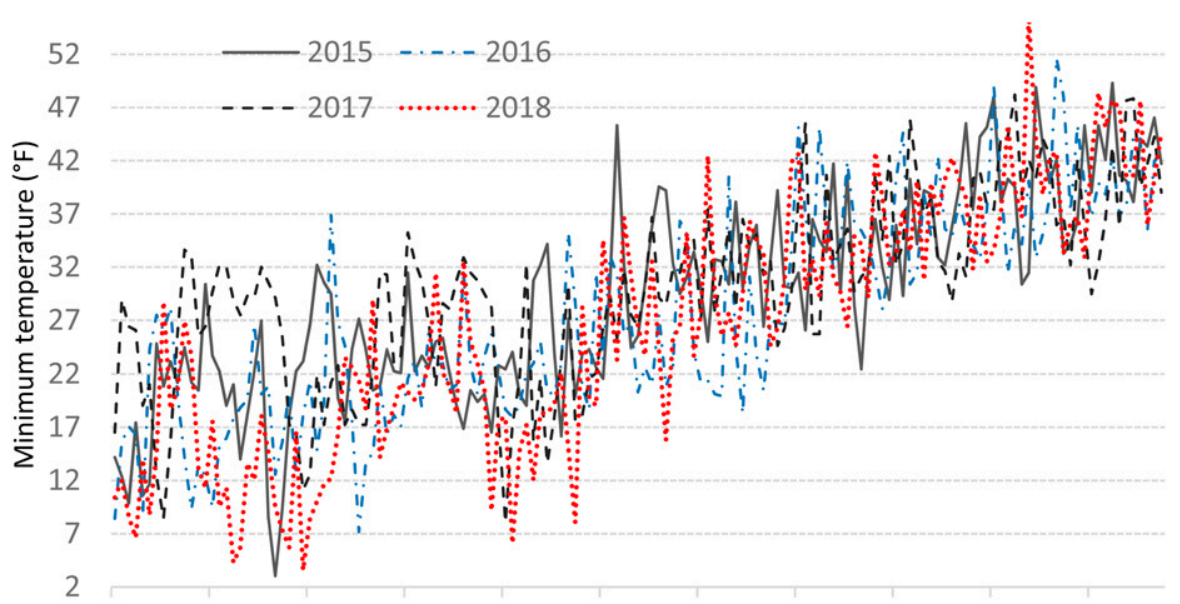

1 Jan. 15 Jan. 29 Jan. 12 Feb. 26 Feb. 12 Mar. 26 Mar. 9 Apr. 23 Apr. 7 May 21 May

Fig. 1. Daily minimum temperatures from 1 Jan. to 31 May 2015-18 at Alcalde, $\mathrm{NM} ;\left({ }^{\circ} \mathrm{F}-32\right) \div 1.8={ }^{\circ} \mathrm{C}$.

flower buds were free from damage. Trees bloomed in mid to late March, and the high tunnels were closed on 20 Mar. The heater inside the high tunnels saved the flowers/fruitlets from late frosts in April and May.

In 2016, temperatures were 3 to $4^{\circ} \mathrm{F}$ colder from late February to early April, and most flower buds and fruitlets were damaged before the heaters started on 20 Mar. Lack of crop in 2016 could also be a result of biennial bearing after the bumper crop in 2015.

In 2017 and 2018, late February/early March freezes below $10{ }^{\circ} \mathrm{F}$ killed most expanded apricot flower buds/flowers. In contrast, in 2018 most other tree fruit species, including japanese plum (Prunus japonica), european plum (Prunus domestica), sweet cherry (Prunus avium), peach (Prunus persica), and apple (Malus domestica), were safe with blooms in late March to April; notably, 2018 was the only year from 2010 to 2018 when there was a crop for the 'Santa Rosa' japanese plum at the Alcalde Center.

Frost DAMAGE AND FLOWER BUD DROP. 'Katy' was the first to bloom each year, and 'Golden Amber' bloomed later and longer than others among the five cultivars tested. 'Katy' can bloom as early as late February at Alcalde, NM, while the last frost date on average is about 9 May each year. Normally, late bloomers have been recommended in frost-prone areas, but for apricot in northern New Mexico, several days' delay in blooming could not solve the late frost problems and save the crop.

After the 2015 crop, there was no crop harvested from 2016 to 2018. We noticed frost damage at different stages of flower development: during dormancy, postdormancy, prebloom, and after bloom. Winter damage to buds can happen before the natural dormancy/chilling requirement is fulfilled (i.e., during endodormancy) or during the period after completion of endodormancy and before bud burst (i.e., during ecodormancy) (Julian et al., 2007).

In northern New Mexico, winter damage during endodormancy is not typically the main concern, but winter damage during ecodormancy in late January to early February can be severe [e.g., the freeze on 3 Feb. 2011 that killed most peach flower buds and some apricot flower buds (Yao, 2011)]. With the huge daily temperature fluctuations in February and March in northern New Mexico, the prebloom frost damage could be worse than or as bad as postbloom frost damage. Ecodormancy winter damage and prebloom frost damage can end flower bud development and cause a high percentage of flower bud drop near bloom or after bloom (Julian et al., 2007).

In 2015, we observed bud drop and blind branch sections, but the remaining flowers were healthy and set fruit. In 2018, from late February to 10 Mar., there were several nights with temperatures as low as 7 to $14{ }^{\circ} \mathrm{F}$, which killed some of the developed flower buds. A high percentage of buds were killed prebloom and dropped, but the remaining ones bloomed with damaged pistils and stamens and twisted petals (Fig. 2). Actually, no full bloom was observed in 2018 , but there were a few scattered flowers. Temperature patterns in 2017 were similar to 2018 in late February to early March. In both years, there were not enough healthy flowers to make a reasonable crop, and heating was ended after bloom. In 2016, there was severe bud drop, and the heavy crop in 2015 also contributed to fewer flowers. There were numerous days with temperatures as low as 18 to $25^{\circ} \mathrm{F}$ from the end of February to early April, which extended the heating season, making it economically uncertain.

Normally, $10 \%$ to $20 \%$ healthy flower buds blooming and setting fruit would ensure a good crop. Julian et al. (2007) showed that apricot trees with $70 \%$ flower bud drop still produced reasonable crops. We observed a similar situation, but whether there is a crop in any given year also depends on the status of the remaining flower buds. If the remaining flower buds are healthy, a crop is possible if they are protected from future late frosts.

From 2010 through 2018, apricots bloomed latest in 2010; they were still blooming on 1-year-old shoots on 12 Apr. and set fruit well, and all fruitlets survived until the $22{ }^{\circ} \mathrm{F}$ frost on 1 May in the field planting at NMSU Alcalde Center (unpublished data). Years like 2010 and 2015 , with a cool spring, without extreme high/low temperatures, and with few frosts after bloom would be ideal years for high tunnel apricot production in northern New Mexico. In years like 2017 and 2018, with cold nights in late February to early March, heating may save flower buds, but the cost of heating may exceed crop income.

\section{Conclusion}

Apricot is still a risky crop even in high tunnels in northern New Mexico. The warm February weather accelerates the flower development, but the late February to early March freezes kill flower buds. Without alternative low-cost heating methods, apricot production in high tunnels is only economically sound in years with 

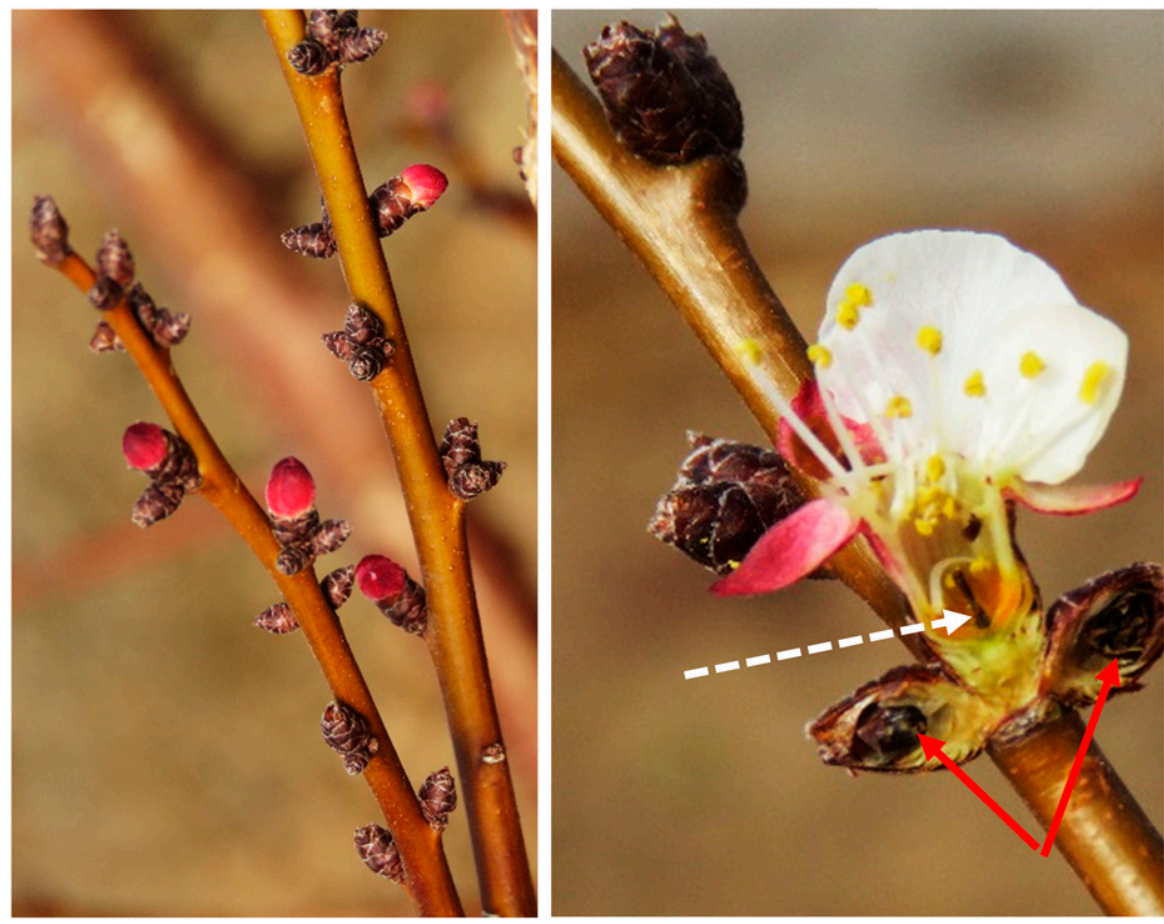

Fig. 2 Damaged apricot flower buds (arrows with solid line) and damaged pistil (arrow with dotted line) inside a blooming flower in 2018 at Alcalde, NM.

mild springs and when trees bloom relatively late, such as occurred in years 2010 and 2015 in northern New Mexico. If heaters are needed to protect the flower buds in late February to mid-March, the cost of fuel may outweigh crop revenue.

\section{Literature cited}

Bassi, D., G. Andalc, and F. Bartolozzi. 1995. Tolerance of apricot to winter temperature fluctuation and spring frost in northern Italy. Acta Hort. 384:315321.
Demchak, C. 2009. Small fruit production in high tunnels. HortTechnology 19:44-49.

Gunes, N.T. 2006. Frost hardiness of some Turkish apricot cultivars during the bloom period. HortScience 41:310-312.

Julian, C., M. Herrero, and J. Rodrigo. 2007. Flower bud drop and pre-blossom frost damage in apricot. J. Appl. Bot. Food Qual. 81:21-25.

Huang, J., R. Heyduck, R. Richins, D. VanLeeuwen, M.A. O'Connell, and S. Yao. 2017. Jujube cultivar vitamin C profile and nutrient dynamics during maturation. HortScience 52:859-867.

New Mexico Climate Center. 2012. Weather stations and data retrieval. 14 Jan. 2019. <https://weather.nmsu.edu/ coop/request/station/290245/data/>.

U.S. Department of Agriculture. 2008. Soil survey of Rio Arriba area, New Mexico, parts of Rio Arriba and Sandoval counties. 11 Feb. 2019. <https://www.nrcs.usda. gov/Internet/FSE_MANUSCRIPTS/ new_mexico/NM650/0/Rio\%20Arriba\% 20Area\%20NM.pdf>.

Western Regional Climate Center. 2019. Cooperative climatological data summaries, Alcalde, New Mexico. 14 Jan. 2019. $<$ https://wrcc.dri.edu/cgi-bin/cliMAIN. pl?nm0245>.

Yao, S. 2011. Winter 2011 low-temperature injury to stone fruit flower buds in New Mexico. HortTechnology 21:767772 .

Yao, S. and C. Rosen. 2011. Primocanefruiting raspberry production in high tunnels in a cold region of the upper midwestern United States. HortTechnology 21:429-434.

Yao, S., J. Huang, and R. Heyduck. 2015a. Jujube (Ziziphus jujuba Mill.) flowering and fruiting in the southwestern United States. HortScience 50:839846.

Yao, S., S.J. Guldan, R.P. Flynn, and C. Ochoa. 2015b. Challenges of strawberry production in high-pH soil at high elevation in the southwestern United States. HortScience 50:254-258.

Yao, S., S.J. Guldan, and R. Heyduck. 2018. Organic blackberry cultivar trials at high elevation and in high $\mathrm{pH}$ soil in the southwest United States. J. Amer. Pomol. Soc. 72:557-561. 